\title{
Analysis on Reasons Why Companies Pay Dividends Jiacheng $\mathrm{Li}$ \\ University of Warwick, Coventry, CV4 7AL, United Kingdom \\ angela@cas-harbour.org
}

Key words: Agency theory, Signaling theory, Dividend.

\begin{abstract}
This paper analyzes the reasons why corporations pay dividend. With the conduct of sample analysis, several opinions are proposed in the paper. Many researchers have put forward important theories, such as agency theory and signaling theory to explain the rationale behind dividend payment. Moreover, Apple's stock performance and its dividend payout are analyzed to give a deeper insight into the existing theories. Lastly, this paper also provides advice on how to improve dividend policy. Further research will be made in the future.
\end{abstract}

\section{Introduction}

Companies tend to hold a large amount of cash that are accumulated by profits or reaped by business activities. Firms need to decide how to distribute these profits. One way to manage these profits is reinvestment, and another method is to pay dividend to shareholders. It is worth mentioning that it is not compulsory for companies to pay dividend. Nevertheless, paying dividend can pose a significant impact on the company. This paper will discuss why some companies pay the dividend while others choose not to do so based on some existing theories. Through using sample analysis, it gives a more specific and practical view when selecting a certain industry or company to analyze the reasons why companies issue dividend. By combining existing theories and sample analysis, it is obvious to find that reducing agency cost and showing a positive prospect of firms will motivate corporations to pay dividend. Moreover, dividend is used to attract new investors. Meanwhile, it is essential to determine how much dividend to pay and through which measure.

\section{Method and Analysis}

\subsection{Reasons for paying dividend}

\subsubsection{Signaling theory}

This theory indicates that companies, who pay dividends, are more appealing to potential investors as they are convinced that dividends demonstrate an optimistic perception of a company's future and they also receive an instant cash inflow. According to Eisemann and Moses [9], their research showed that most managers are prone to follow the signaling theory by examining firms that pay dividends and those who do not pay dividends. The cash flow signaling theory of dividends states that managers receive more information than stakeholders, such as major investment opportunities $[6,7,8]$. Thus, mangers tend to convey this favorable message by paying dividend, and investors would react positively to this action. Furthermore, dividends are a signal of steady income of corporations [3]. Therefore, the managers believed that dividends showed their confidence in their firms' future.

\subsubsection{Agency theory}

Agency theory suggests that the separation of ownership and management is another plausible explanation for dividend payout. It assumes that managers may pursue their own interests at the cost of stockholders' wealth. For example, managers may take on value-reducing investment, such as projects with negative NPV. The excessive free cash flow makes it easier for managers to conduct such behavior. The cost monitoring and bonding is known as agency cost. Dividend, then, is used to reduce the amount of free cash flow and help firms avoid abusive use of corporate resources by managers. DeAngelo, et al. [2] reinforced that dividends help to protect firms from massive money 
reserve and also from improper managerial behaviour, who can use retained earnings of a company for inappropriate aims. Thus, dividend is an important financial tool to reduce agency cost.

\subsubsection{For investors}

Investor are more likely to invest in stocks if they complement with dividends. Allen et al. [1] agreed that companies which pay dividends are more attractive to investors. Investors perceive dividends as a sign of well management and great prospect of firms. According to Juma'h and Pacheco [5], shareholders have a preference towards dividend paying firm because this kind of firm is less risky. Sullivan [11] stresses that the dividend paying firms have a high value on the market. $\mathrm{He}$ also gives an example and states that 373 companies out of 500 in the Standard \& Poor index pay dividend. And these firms are more attractive to investors than a non dividend-paying firm. Thus, dividend payments stimulate demand for such firms and therefore, it drives up stock prices. Grinblatt supports this view that the share price is positively correlated with announcement of the dividends. Doran and Nachtmann as well as McNicoles and David proved earning significantly increased following the insurance of dividends[1].

\subsubsection{Apples' case}

Given that the plummeting share price of Apple (\$420) between 2012 and 2013(see Exhibit 1), the investors of Apple concerned about the extremely high level of cash holding ( $\$ 137$ billion). A potential principle-agent conflict arose thus the investors suspected that there was a mismanagement of retained earnings. To cope with the increasing pressure from shareholders, Apple announced that it would issue a quarterly dividend, which would begin in July of 2012, and the investors would expect their dividend in November. With the announcement of dividends, Apple's share price bounced back by $15 \%$ to $\$ 593.83$ in the morning trading[10]. Likewise, in May of 2019, it was found that an increase of 5\% in Apple's dividend payment led to a rise of 5.4\% in its share price in after-hour trading [4]. This is consistent with the discovery of Ginblatt. It is noticed that Apples's dividend and share price always move in the same direction, which further supports the view of positive correlation between share price and dividend payout.

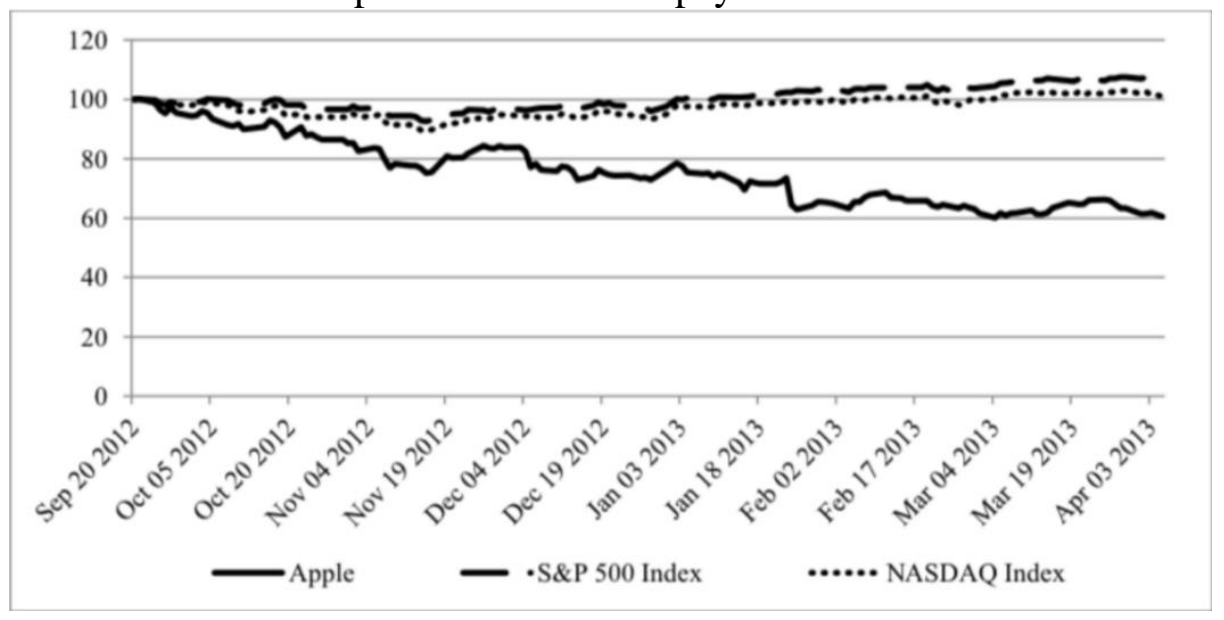

Exhibit 1 Stock performance of APPLE between 2012 and 2013

\subsection{Possible problems for paying dividend}

\subsubsection{Funding growth}

Dividends are issued out of a business's retained earnings, and issuing dividend means the total amount of cash flow available decrease. If a company decides to expand, for example, a new store in a new place, it needs sufficient fund to financially support this decision. For companies that are growing, dividend payouts may limit their ability to invest in new project that can grow firm value. Prosperous firms do not pay dividends because internal financing is cheaper than borrowing. Dividend payment reduces internal cash flow and thus external financing is desired, such as loan from banks. However, borrowing cost can be high. Moreover, the high potential expense of issuing new stocks may also be another reason that companies choose to reinvest all of their profits rather than pay dividend. Firms choose to reinvest all of their earnings. To avoid the risk of needing to 
raise money this way, they choose to retain all of the profits. Hence, dividend payment may lead to slow growth of business. This problem can be more severe for smaller growing companies.

2.2.2 Negative signal

A company may also choose not to pay dividends because the decision to start paying dividends or to increase an existing dividend payment is a serious issue. As signaling theory suggests, a company that suspends or decreases its existing dividend payment may send an unfavorable signal to investors. Firms pay dividend to maintain the historical practice of paying their investors a portion of profits that they earned. Once dividend is first issued, investors have an expectation of continuous dividend payment. Therefore, if firms stop paying dividend, this might terrify investors and they may view such suspension of dividends as a signal of a financial strain. As a result, investors might lose confidence in the company and sell their shares.

\subsection{Brief summary}

Agency theory and signaling theory can explain why corporations pay dividends. Furthermore, reducing agency cost and creating a positive perception of companies' future motivate corporations to issue dividend. More importantly, dividend pushes demand for stock and therefore stimulates stock price. However, dividend payout may deplete funds available to finance the growth of corporations. Furthermore, dividend decrease may result in loss of confidence of investors as they consider the cut as a downturn of companies.

\section{Discussion}

Dividend, as a financial tool, can show a strong prospect of corporation as well as give confidence to investors that their investment is well-managed. It is found that any change in the dividend payout can have a significant impact on company. The problem of paying dividend is that investors expect perpetual dividend payment once they receive one, and they expect the dividend to grow. Any sudden adverse change in dividend payment would incur an unfavorable perception of the business. Therefore, it is indispensable to keep a stable stream of dividend. When a corporation determines dividend size, it should take account into the following factors: a company's financing needs, macroeconomic, market conditions, taxation and legislation payment. The key point is to determine the size of dividend and payout procedure. One possible solution is to set a fixed dividend payout ratio, which is the total amount of dividend relative to the net profits of the business in different circumstances and present this in the dividend policy. For instance, with no plan of expanding or major investment opportunities, dividend payout ratio can be high, depending on the amount of net profits reaped in that year. On the other hand, if in the circumstance of expansion, dividend payout ratio can be relatively low, allowing companies to have sufficient funds for new projects. In this way, it is a good way to inform investors of the current status of company and reduce information asymmetry, preventing conflicts between investors and managers. The dividend is no longer extrapolated as a negative signal, but a sign of future growth of the company, and hence it mitigates the effect of dividend cut.

\section{Conclusion}

In spite of the disadvantages of paying dividends, firms in most cases make a decision to pay dividend to their shareholders because it helps corporations to attract new investors from the market, to demonstrate good results in companies' performance, to control improper managerial behavior and besides the dividends can solve the problem of immense money reserve. For dividend-paying firms, it is crucial for them to make dividend payment regularly. Suspension or decrease of dividend may arouse suspect of financial health. Paying dividend reduces internal cash flow and hence decreases the ability of internal financing. One of the limitations of this thesis is that it pays more attention to the benefits of paying dividend rather than focuses on the problem of paying dividend, which creates a bias. Other problems such as the tax disadvantages are neglected. Therefore, this paper cannot give exact suggestions on how to improve dividend policy for existing problems, but 
in the future, further research will dig into the complications of paying dividend and improvements to dividend policy.

\section{Acknowledgement}

First and foremost, I would like to show my deepest gratitude to my teachers and professors in my university, who have provided me with valuable guidance in every stage of the writing of this thesis. Further, I would like to thank all my friends and roommates for their encouragement and support. Without all their enlightening instruction and impressive kindness, I could not have completed my thesis.

\section{References}

[1] Allen, Franklin, Antonio Bernardo and Ivo Welch, A theory of dividends based on tax clientele, Journal of Finance, Vol. 55, No. 6, pp. 2499-2536, 2000.

[2] H. DeAngelo, L. DeAngeloa, R. M. Stulz, Dividend policy and the earned/contributed capital mix: a test of the life-cycle theory, Journal of Financial, 2006.

[3] Feldstein, Martin and Green, Jerry, Why do companies pay Dividends? American Economic Review, Vol. 73, No. 1, pp. 17-30, 1983.

[4] Hargreaves Lansdown, Apple-surprise dividend increase lifts shares, 2019. [Online] Available at: https://www.hl.co.uk/shares/share-research/201905/apple?surprise-dividend-increase-lifts-share s [Accessed on 27 Oct. 2019].

[5] A. H. Juma'h and C. J. Pacheco, The Financial Factors Influencing Cash DividendPolicy: A Sample of U. S. Manufacturing Companies, International Metro Business Journal, Vol. 4, No. 2, 23-43, 2008.

[6] K.John and J. Williams, Dividends, dilution, and taxes: a signalling equilibrium, The Journal of Finance, Vol. 40, No. 4, pp. 1053-70, 1985.

[7] K.Khang and D. King, Is dividend policy related to information asymmetry: evidence from insider trading gains, AFA Washington DC Meetings, 2003.

[8] M. H.Miller and K. Rock, Dividend policy under asymmetric information, Journal of Finance, Vol. 40, No. 4, pp. 1031-51,1985.

[9] C. Eisemann Peter and A. Moses Edward, Stock Dividends: Management's View, Financial Analysts Journal, 1978.

[10]D. Rushe, Apple shares cash pile as it launches dividend and share buyback scheme, the Guardian, 2012. [Online] Available:

https://www.theguardian.com/technology/2012/mar/19/apple-dividend-share?buyback

[Accessed on 27 Oct. 2019].

[11]P.Sullivan, Assessing the Value of Dividend-Paying Stocks, Nytimes. com, 2011. [Online]Available: https://www.nytimes.com/2011/06/04/your-money/stocks-and-bonds/04wealth.html [Accessed on 3 Dec. 2019]. 